2.

Reformmöglichkeiten:

Wege zu verbesserter Repräsentation /

Curing the System: The Road to Better Representation 



\section{Migration, Representative Democracy and Residence Based Voting Rights in Post-Apartheid South Africa and Post- Unification Germany (1990-2015)}

Wessel le Roux*

Over the past 25 years migration has surfaced as one of the core features of globalisation to impact on established constitutional democracies from the North (such as Germany) and young constitutional democracies from the South (such as South Africa). Nancy Fraser claims that migration has forced all self-proclaimed democracies into a state of 'abnormal justice' by placing the meaning of 'the people' or the demos in the representative State into question. The 'abnormal' nature of contemporary constitutional jurisprudence is perfectly illustrated by a number of recent voting rights cases in South Africa and Germany. These cases reveal two Constitutional Courts caught up in the transition between two constitutional models of political participation. The old model of citizenship places nationality (naturalisation) and the principle of 'equal citizenship' central; the new model of denizenship places residence and the principle of 'all affected persons' central. The case law discussed below is marked by tensions, contradictions, unexplained shifts and inversions as the Constitutional Courts of South Africa and Germany struggle in search of a new principled basis to regulate the voting rights of migrants.

* The research for this article was made possible by a staff mobility grant from the Erasmus Mundus action 2 South Africa (ema2sa) programme. I owe much more than the normal word of thanks to Dr. Dominik Steiger and Dr. Nils Schaks for their warm hospitality during my stay at the FU Berlin during the winter of 2013-2014. I also wish to thank Dr. Helmut Aust for alerting me to the complex modalities of postnational democracy and representation. 


\section{A. Introduction}

The members of the Bundestag in Germany and the National Assembly in South Africa are elected to represent 'the people' of each Republic. ${ }^{1}$ It is no longer clear what this basic tenet of representative democracy entails. Globalisation and migration have placed both 'the people' and the modalities of its representation into question. ${ }^{2}$ Nancy Fraser claims that we find ourselves in the midst of an era of 'abnormal justice'. ${ }^{3}$ As Sofia Näsström puts it, in this era 'the people' has changed from constitutional 'presupposition' to constitutional 'problem'; constitutional law has shifted its focus from 'rule-making' to 'people-making'. ${ }^{4}$

In this context, demands for democratic inclusion and representation are increasingly posed by or on behalf of four distinguishable groups of people: (i) citizens residing inside the borders of the State; (ii) citizens residing outside the borders of the State; (iii) foreigners residing inside the borders of the state; and (iv) foreigners residing outside the borders of the state.

The task of the national legislature was traditionally confined to the first issue. The democratisation of representative democracy has unfolded on the assumption that the national legislature has the duty to equally represent all citizens. This assumption sustained many struggles for equal voting rights during the $20^{\text {th }}$ century (not least the armed struggle in South Africa against apartheid). Given this history, many States have tried to resolve the new democratic claims of the other three categories mentioned above on the basis of the old and established model of equal citizenship.

1 Basic Law for the Federal Republic of Germany, 1949, article 38(1) read with article 20(2); Constitution of the Republic of South Africa, 1996, section 42(3).

2 I restrict my focus here to the right to be represented in the national legislature. I also restrict my focus to the right to direct or actual representation (as opposed to virtual representation). The question of 'the people' thus becomes the question of 'the electorate' or the right to vote. See Frank Michelman, Traces of self-government, Harvard LR 100 (1986), pp. 50-55 (on virtual representation), and Elizabeth Cohen, Dilemmas of representation, citizenship, and semi-citizenship, Saint Louis University Law Journal 58 (2014), p. 1047 (on virtual representation as a form of trusteeship).

3 Nancy Fraser, Transnationalizing the public sphere, Cambridge, 2014, p. 36. The abnormality stems from the fact that membership of the people itself is contested, not only the rights members owe each other.

4 Sofia Näsström, The challenge of the All-Affected Principle, Political Studies 59 (2011), p. 116. 
The paper below explores the success of this strategy by comparing the impact of migration on the voting rights jurisprudence of post-apartheid South Africa and post-unification Germany. Both jurisdictions are marked by a conflict between an old and a new constitutional paradigm for the political integration of migrant workers. The old model continues to allocate voting rights to migrants on the basis of equal citizenship, broadly resulting in voting rights for non-resident citizens (category two claims above) but not for resident non-citizens (category three claims above). The new model seeks to allocate voting rights to migrants on the basis of equal residence or denizenship, broadly resulting in the voting rights of resident foreigners (category three claims) but not for non-resident citizens (category two claims).

After exploring the tension between the two models in South African law (section B) and German law (section C), I argue in conclusion (section D) that the tension between the two models should be resolved at the national level in favour of the new model of denizenship or universal residence based voting rights. This model has the potential to revitalise and enhance the democratic legitimacy of national representative governments by including 'all affected persons' in the demos. Only the latter principle is able to inspire a transnational democratic response to inter-regional migration (and other challenges of globalisation, such as global capitalism and global climate change) by recognising the political right of non-resident foreigners to be represented when laws and policies are made that directly affect them (category four claims above) ${ }^{5}$

5 This does not mean that non-resident foreigners must be allowed to vote in national elections. Even if the right of non-resident foreigners to be included in the demos is recognised, the modalities of membership and participation still need to be determined. I return to this issue below in Section E. For more detail refer to David Owen, Transnational citizenship and the democratic state: On modes of membership and rights of political participation, in Satvinder Juss (ed.), The Ashgate Research Companion to Migration Law, Theory and Policy, 2013, p. 689; Eyal Benvenisti, Sovereigns as trustees of humanity: on the accountability of states to foreign stakeholders, American J Int L 107 (2013), p. 295; Robert Goodin, Enfranchising all affected interests, and its alternatives, Philosophy and Public Affairs 35 (2007), p. 40; and Arash Abizadeh, Democratic theory and border coercion: No right to unilaterally control your borders, Political Theory 36 (2008), p 37. 


\section{B. The voting rights of migrant workers in post-apartheid South Africa}

During the first quarter of a century after apartheid five national elections took place in South Africa. Not two of those elections applied the same voter eligibility criteria to migrant workers. On the contrary, the history of voting rights in South Africa is characterised by often dramatic and unexpected policy shifts. Here is the story.

\section{Celebrating residence: the 1994 elections}

After decades of violent struggle for equal political rights in South Africa, the interim Constitution of 1993 contained not one, but two provisions regulating the right to vote. Each provision strangely contained its own set of voter eligibility criteria. On the one hand, section 21(1) of the Bill of Rights stipulated that '[e]very citizen shall have the right to vote', implying that foreign nationals may not be granted the right to vote. Section 6(a) (ii) of the Constitution, on the other hand, provided explicitly that an Act of Parliament may extend the right to vote in national elections to foreign nationals. Read together, the interim Constitution neither mandated nor prohibited the inclusion of foreigner nationals. The matter was entirely left to the discretion of Parliament. Parliament responded by extending the right to vote to two groups of migrant workers: foreigners with permanent resident status in South Africa, and foreign residents without such status but who had entered the Republic before 13 June $1986 .{ }^{6}$ Because the first post-apartheid elections did not include a voter registration process, eligible voters without official South African documents could apply for a temporary voter card and proceed to vote. More than 3.5 million temporary voter's cards were issued on this basis. According to standard estimates, this number included 500000 foreign nationals who voted in the 1994 national and provincial elections. ${ }^{7}$

How should we understand this almost unprecedented embrace of foreigner voting rights immediately after the end of apartheid? One answer is that it was a conscious constitutional decision to rebuild post-apartheid South Africa on the basis of a radically post-nationalist and post-colonial

6 Section 15 read with section 1 of the Electoral Act 202 of 1993.

7 Susan Booysen and Grant Masterson, Chapter 11: South Africa, in: Denis Kadima and Susan Booysen (eds.), Johannesburg, 2009, p. 405-406. 
model of representative democracy (in direct reaction to the perverted Christian Nationalism of the former apartheid regime). In terms of this post-nationalist constitutional model, the task of the National Assembly was decidedly not to represent the South African nation, but to represent the resident population of South Africa. By extending full voting rights to foreign residents, the interim Constitution of 1993 separated nation and state and completed the disaggregation of citizenship into denizenship. ${ }^{8}$

There are both pragmatic and principled reasons why this preference for denizenship would have made good sense at the beginning of the 1990s. In a deeply divided society on the verge of a civil war, democracy could hardly have been conceived in nationalist terms (ethno-cultural or civic). Political participation on the basis of 'constitutional patriotism' provided the only possibility for the future social and cultural integration (and transformation) of society. ${ }^{9}$ Political participation in a peaceful election on the basis of residence became the precondition for national-building and socio-cultural integration.

Secondly, a truly transformative political rights jurisprudence in postapartheid South Africa was only possible on the basis of denizenship. Apartheid constitutionalism was a disastrous attempt to solve the problem of equal voting rights through the manipulation of migration and immigration law. The solution was to turn all black South Africans into foreign residents by converting their nationality into that of a number of independent black homelands. (White) South Africa thereby became the 'host country' of millions of migrant workers from a number of (black) neigh-

8 Seyla Benhabib, The rights of others: Aliens, Residents and citizens, Cambridge, 2004, p. 171 describes 'disaggregated citizenship' both as a reality and normative ideal in the era of globalisation. The end-point of this disaggregation process is denizenship. The post-apartheid Constitutions mandate the disaggregation of citizenship by extending all rights to 'everyone' under the territorial jurisdiction of the state. One exception was the right to vote. Under the 1993 Constitution, the disaggregation of voting rights was not mandated (under section 19(1)) but permissible (under section 6). The same position applies arguably under the 1996 Constitution as well. Resistance to disaggregated citizenship or denizenship is not limited to political rights. In Khosa v Minister of Social Development; Mahlaule v Minister of Social Development [2004] ZACC 11; 2004 (6) SA 505 (CC) Ngcobo J ruled that the right of all residents to social security need not be strictly implemented, but can be limited to citizens only, in order to encourage the naturalisation of foreigner nationals.

9 Jan-Werner Müller, Constitutional patriotism, Princeton, 2006, pp. 46-90. 
bouring 'home countries'. ${ }^{10}$ This constitutional model (or grand apartheid) rested on the traditional constitutional distinction between citizens and foreign residents, and the equally traditional doctrine that foreign nationals do not have a legitimate claim to political rights in host countries. This controversial constitutional model was officially abandoned in $1986 .{ }^{11} \mathrm{Be}-$ tween 1986 and 1994 South Africans negotiated a relatively peaceful transition to an alternative democratic constitutional model.

Two alternatives to apartheid constitutionalism presented themselves. According to the citizenship model, the problem with grand apartheid was the sharp distinction between black and white citizens. The solution required the recognition and normalisation of equal citizenship. According to the denizenship model, the problem with grand apartheid was the sharp distinction between foreign residents and citizens. The solution to apartheid required the complete disaggregation of citizenship rights, that is, the recognition of political rights as constitutive of the dignity of all residents as participatory subjects of law, as opposed to objects of state power. The deeper logic of apartheid could be transformed only if the nationalist model of equal citizenship was also transformed. Hence the extension of voting rights to all residents in the first post-apartheid elections.

Attractive as this interpretation of the voting rights provisions of the 1993 Constitution and the significance of residence based voting rights might be, a number of South African constitutional scholars tell a different story about the first democratic elections. Jonathan Klaaren and Claire Robinson both insist that the recognition of foreigner voting rights in these elections was no more than a strategic deal between the major negotiating

10 See the Bantu Homelands Citizenship Act 26 of 1970. Between 1976 and 1981, four homelands (Transkei, Venda, Bophuthatswana, and Ciskei) were declared 'independent' and eight million black South Africans lost their South African citizenship. The apartheid framework included not only the homelands, but also the hinterlands of white South Africa (Malawi; Mozambique; Zambia). It was from here that the majority of migrant mine labourers came. The failure to implement a truly transformative model of political rights (read denizenship) means that the apartheid model of hinterlands remains in place.

11 Sampie Terreblanche, Lost in transformation: South Africa's search for a new future since 1986, Johannesburg, 2012, pp. 7-16 explains from a slightly different angle why 1986 was the real turning point in South Africa's transformation. As part of a comprehensive new legislative framework, The Matters Concerning Admission to and Residence in the Republic Amendment Act 53 of 1986 came into operation on 13 June 1986. The Act introduced the possibility for black foreigners to acquire South African citizenship through naturalisation. 
parties. ${ }^{12}$ The agreement was simple: keep voter exclusions to a minimum, thereby avoiding potential incidences of election violence and enlarging the support-base of all parties. Pacheka Ncholo suggests (less cynically) that the recognition of foreigner voting rights was simply a pragmatic response to the various unjust nationality regimes which were applicable in South Africa at the end of apartheid. ${ }^{13}$ Far from celebrating an alternative post-apartheid model of denizenship, the granting of voting rights to foreign residents was simply the first step towards the normalisation of the conventional model of equal citizenship. The strongest support for Ncholo's interpretation is the fact that the post-apartheid experiment with foreigner voting rights did not survive the drafting of the final Constitution of 1996 into the next national elections.

\section{Combining residence with nationality: the 1999 elections}

South Africa's current Constitution (the so-called final Constitution of 1996) was drafted between the 1994 and 1999 national elections. While the preamble of the Constitution confirmed that 'South Africa belongs to all who live in it', and section 1 declared that 'universal adult suffrage' was a foundational value, and the Bill of Rights again extended disaggregated citizenship rights to 'everyone' within the borders of South Africa, the Constitution did not again make provision for the voting rights of foreign nationals as required by the model of denizenship. On the contrary, the wording of the right to vote in section 19(3) of the Bill of Rights returned to the model of equal citizenship by limiting the right to vote to all adult citizens. The Electoral Act 73 of 1998 dramatically confirmed the exclusivity which the new constitution ascribed to the right to vote. In sharp contrast with its predecessor, the new Act explicitly prohibited the registration of foreign nationals as voters. ${ }^{14}$ The Act nevertheless retained some commitment to residence from the discarded denizenship model. It

12 Jonathan Klaaren, Contested citizenship in South Africa, in: Penelope Andrews and Stephen Allman (eds.), The post-apartheid Constitutions, Ohio, 2001, p. 309; Claire Robertson, Contesting the contest: negotiating the election machinery, in: Steven Friedman and Doreen Atkinson, The small miracle: South Africa's negotiated settlement, Johannesburg, 1994, p. 44.

13 Pacheka Ncholo, The right to vote, in: Nico Steytler (ed.), Free and Fair Elections, Kenwyn, 1994, p 64.

14 Section 8(2)(b) of the Electoral Act, 1998. 
stipulated that citizens could only be registered as voters if they were ordinarily resident in South Africa, and that registered voters had to vote at their places of ordinary residence. ${ }^{15}$

Apart from disenfranchising migrant workers in South Africa, the combination of the ordinary residence and citizenship requirements also had far-reaching consequences for South African migrant workers abroad. The Act effectively divided migrant workers abroad into those who were temporarily abroad with an obligation to return (without permanent residence status abroad), and those with the intention and right to permanently remain abroad (emigrants or expatriates with permanent residence status abroad). Citizens in the first category remained ordinarily resident in South Africa and thus eligible to register and vote. Citizens in the second category had to be deregistered as voters. As a result, migrant workers abroad either lost their right to vote in South Africa, or became constructively disenfranchised (given that the Act did not contain a generally accessible absentee voting rights procedure).

This dramatic restriction of the right to vote reflected the view that citizenship had finally been normalised. It was thus no longer necessary to accommodate special groups of migrants outside the norm (by then exiles had returned home and migrant workers from the hinterlands of South Africa had been naturalised through a series of immigration amnesties). ${ }^{16}$ The new Electoral Act also reflected a negative policy stance towards migration in general and towards the unprecedented skills drain from South Africa which tended to reflect racial contours and thus resulted in large, mostly white, South African expatriate communities abroad.

While the disenfranchisement of foreign nationals during the 1999 elections went by unchallenged (another sign of normalisation?), the constitutionality of the ordinary residence requirement and its disenfranchising effect on citizens soon made its way to the Constitutional Court. In August $v$ Electoral Commission (the Court's first voting rights case) the South African Constitutional Court (SACC) was faced with the task of establish-

15 Section 8(2)(e) of the Electoral Act, 1998 prescribed that only citizens who were 'ordinarily resident' in South Africa could be registered as voters.

16 This conviction was so pervasive that the Constitutional Court boldly ruled that citizens who had by then not yet obtained the apartheid era bar-coded identification book (an ironic sign of normalisation) could justifiably be excluded from participating in the 1999 election, see New National Party $v$ Government of the Republic of South Africa [1999] ZACC 5; 1999 (3) SA 191 (CC). 
ing whether, and if so why, residence was significant enough to trump citizenship as voter eligibility criteria. ${ }^{17}$ The case involved citizens detained in prisons. The Electoral Commission (EC) had simply assumed that prisoners were not ordinarily resident in prison and that prisoners were thus prevented by their personal circumstances from voting in the 1999 election. No steps were taken to register prisoners or to set up polling stations in prisons. Prisoners claimed that this omission violated their right to vote. The Court ruled in favour of the prisoners, but judiciously avoided the broader debate about the constitutional significance of the residence requirement by ruling that prisoners were ordinarily resident in prison, and that the EC therefore had to ensure that all prisoners could register and vote in prison.

The willingness of the Court to manipulate, if not ignore, the 'ordinary residence' requirement in order to avoid the disenfranchisement of prisoners set the tone for many of the Court's subsequent voting rights cases. In August the Court explicitly celebrated voting rights as the 'badge' which distinguished dignified citizens (including prisoners) from mere residents. ${ }^{18}$ This celebration of the equal dignity of citizens resulted in a very truncated understanding of the constitutional significance (and implied constitutionality) of the ordinary resident requirement in the new Act:

The purpose of the phrase 'ordinarily resident' is to facilitate the electoral process. It will, for example, enable the allocation of voters to voting districts, each with their own polling stations, so that an identified and relatively small number of voters resident in that district during the period of registration and voting will vote in it. [...] This will facilitate easy and accurate identification on voting day and prevent long queues. ${ }^{19}$

While a full exploration of the constitutional meaning of residence was not required to decide the August case, residence based voting was reduced in the case to a logistical consideration, important enough to exclude certain citizens, but only in order to ensure that elections based exclusively on citizenship were properly administrated. The full effects of this subtle judicial dismantling of denizenship by the Court in its first vot-

17 August v Electoral Commission [1999] ZACC 3; 1999 (3) SA 1 (CC) para 27.

18 Henk Botha, The rights of foreigners: dignity, citizenship and the right to have rights, South African Law Journal 130 (2013), p. 837.

19 August, note 17, para 27. 
ing rights case were not immediately felt in the August case, but became clear in later voting rights cases, especially those involving the voting rights of absent and non-resident citizens.

III. Contesting residence: the 2003 and 2009 elections

Before the 2004 election, the Electoral Commission requested the government to recognise external voting rights and formalise an absentee voting procedure for the benefit of citizens abroad. As a result of this request, the Electoral Act was amended in 2003 to extend external voting rights to citizens who were unable to vote at their place of residence due to a 'temporary absence' abroad as a result of a holiday, business trip, sports event, or tertiary studies. ${ }^{20}$ Citizens who were temporarily working overseas were noticeably not included on this list. This omission was not a legislative oversight. The drafting of the list was inspired by the same anti-migration stance that informed the Electoral Act as a whole. During the parliamentary debate on the new provision, migrant workers abroad were repeatedly singled out as unpatriotic and disloyal citizens who did not deserve to be encouraged or rewarded with the right to vote. ${ }^{21}$

This negative stance became the subject of judicial scrutiny shortly before the 2009 elections, when a South African citizen who was working in London as a teacher on a three year contract contested the fact that he had to travel back to his place of ordinary residence in South Africa in order to vote in the election. ${ }^{22}$ In Richter $v$ Minister of Home Affairs the Court ruled that the state had a positive obligation to extend external voting rights to all registered voters abroad, thus taking a far more progressive stance on the issue of external voting rights than the European Court of

20 Section 33(1)(e) of the Electoral Act, 1998 (as amended in 2003).

21 For the full debate in the standing committee, see https://pmg.org.za/committeemeeting/2833/ (last accessed 20 February 2015). The drafting history is described and criticised in more detail in Richter v Minister of Home Affairs [2009] ZAGPHC 21; [2009] 2 All SA 390 (T), para 11.

22 Richter v Minister for Home Affairs [2009] ZACC 3; 2009 (3) SA 615 (CC), para 52. See Wessel le Roux, Migration, street democracy and expatriate voting rights, South African Public Law 24 (2009), p. 370 for a fuller discussion and critique of the judgment. 
Human Rights, for example. ${ }^{23}$ In the process the Court explicitly discredit any suggestion that citizens living and working abroad had deserted their duties of citizenship and could thus be denied their right to vote as part of a policy to discourage migration. ${ }^{24}$

The Richter judgment was widely hailed for its attempt to encourage the ongoing political participation of citizens abroad. In the process of doing so, the Court again failed to appreciate or attach any constitutional weight to the residence requirement in the Act. The Court's failure to do so resulted in confusion about the implications of its order. Without hearing argument on the issue or providing reasons for its judgment, the Court held that registered citizens no longer needed to establish that they were only temporarily absent from (that is, that they are still ordinary resident in) the country, when applying for a special absentee ballot. It was unclear whether this meant that the Court thereby extended external voting rights to expatriate (non-resident) citizens as well. The expatriate voting rights lobby seized the opportunity to argue that it did. In the hope of getting clarity on the issue, a number of opposition parties and expatriate lobby groups decided to directly attack the constitutionality of the ordinary residence requirement. In AParty v Minister of Home Affairs the Court was again faced with the task of exploring the constitutional and democratic significance of ordinary residence as a voter eligibility criterium. ${ }^{25}$ Once

23 Compare the position of the Constitutional Court with that of the European Court of Human Rights which ruled recently in Sitaropoulos and Giakoumopoulos $v$ Greece (ECHR case 42202/07), 12 March 2012, para 69, that the right to vote under the European Convention does not include the right to cast an absentee ballot. The same applied, according to the Court, in international and regional human rights law (para 72).

24 Richter, note 22, para 69: '[W] now live in a global economy which provides opportunities to South African citizens and citizens from other countries to study and work in countries other than their own. The experience that they gain will enrich our society when they return, and will no doubt enrich, too, a sense of a shared global citizenship. The evidence before us, too, shows that many South African citizens abroad make remittances to family members in South Africa while they are abroad, or save money to buy a house. To the extent that citizens engaged in such pursuits want to take the trouble to participate in elections while abroad, it is an expression both of their continued commitment to our country and their civicmindedness from which our democracy will benefit'.

25 AParty v Minister for Home Affairs, Moloko v Minister for Home Affairs [2009] ZACC 4; 2009 (3) SA 649 (CC). 
again the Court managed to avoid the issue, this time by denying the applicants direct access.

The Richter and AParty judgments left the ordinary residence requirement in place for the 2009 elections, but with serious doubts whether the requirement served any democratic purpose beyond its role in facilitating the effective administration of national elections (in which case it could hardly continue to justify the exclusion of any citizens on the basis of their migration status). The ongoing failure of the Court to understand and its refusal to clarify the constitutional significance of residence as a principle of democratic inclusion (and exclusion), left the principle vulnerable and finally resulted in its abolition shortly before the 2014 national elections.

\section{Dispensing with residence: the 2014 elections}

After the AParty case, the expatriate voting rights lobby abandoned their litigation campaign and concentrated their attention on the political process. Buoyed by the global trend towards the recognition of expatriate voting rights, ${ }^{26}$ and by the turn of the African Union towards the African diaspora as a catalyst for Africa's future economic, cultural and political development, ${ }^{27}$ the lobby called for a complete repeal of the ordinary residence requirement in national elections (some extended the call to provincial elections as well). In December 2013 the government made an aboutturn in its attitude towards migrant workers abroad and amended the Electoral Act to allow all expatriate citizens to register as voters and vote in national elections. The amended and current Electoral Act does so by creating an overseas section in the national common voters roll (a tenth province as it were). Any citizen who is not ordinarily resident in South Africa has the right to have his or her name registered in this overseas section of the voters roll, ${ }^{28}$ and to apply for an absentee vote before each election. ${ }^{29}$

26 Also noted in Richter note 22, para 77.

27 African Union: Agenda 2063, para 68. Available at http://agenda2063.au.int/en/ sites/default/files/agenda2063_popular_version_05092014_EN.pdf (last accessed 10 March 2015).

28 Section 8(3) of the Electoral Act, 1998.

29 Section 33(4) of the Electoral Act, 1998. 
Under South African nationality law which recognises the ius sangui$n i s,{ }^{30}$ the amendment of the residence requirement extended voting rights to second and third generation emigrants purely on the basis of their formal status as South African citizens. In spite of its potential reach, only 6789 expatriates registered as overseas voters during the 2014 general elections (a total of 18446 special absentee ballots were cast by overseas voters, including those of temporary absent voters). ${ }^{31}$ Nevertheless, the original residence requirement had finally lost its character as a voter eligibility requirement. It was no more than a logistical factor which determined the mode and place of voting.

\section{Conclusion}

The post-apartheid response to the voting rights of migrant workers is neatly framed by the 1994 and 2014 national elections. In twenty short years, South Africa has moved from a model of denizenship in which voter eligibility was based purely on residence, to a model of citizenship in which voter eligibility is based purely on nationality. What stands out form the brief discussion above is the spectacular manner in which South Africa has embraced the broader global trend towards the granting of voting rights to non-resident citizens, not only by simply neglecting the voting rights of resident non-citizens, but by actively disenfranchising foreign nationals on a large scale. The constitutionality of this dramatic shift has not yet been tested. It remains an open question whether it would be constitutional under the 1996 Constitution to reintroduce foreigner voting rights, or to revoke expatriate voting rights. An answer to these questions would require a proper engagement with the merits of residence as a principle of democratic inclusion. It is precisely such an engagement which is absent from the Constitutional Court's voting rights jurisprudence.

To compensate for this absence and to dispel what Theunis Roux describes as the 'democratic agnosticism' of the South African voting rights jurisprudence, ${ }^{32}$ I turn in the next section to the migrant voting rights cases

30 Section 2(1)(b) of the Citizenship Act of 1995.

31 http://www.elections.org.za/content/NPEPublicReports/291/Voter\%20Turnout/ National.pdf.

32 Theunis Roux, The politics of principle: The first South African Constitutional Court, 1995-2005, Cambridge, 2013, p. 334. 
of the Federal Constitutional Court of Germany in the period after re-unification. As is the case in South Africa, this jurisprudence is marked by a tension between the model of citizenship and denizenship, or in the terms of the German debate, between Volksdemokratie and Betroffenheitsdemokratie, each with its own understanding of the constitutional significance of residence as basis for political participation.

\section{The voting rights of migrant workers in post-unification Germany}

I. The voting rights of resident foreigners

The German Federal Constitutional Court (FCC) controversially ruled in 1990 that the extension of voting rights to foreign residents at local government level undermined the democratic character of the German state and was thus unconstitutional under the Basic Law. ${ }^{33}$ This judgment rested on the claim that the Basic Law implicitly defined 'the people' as the German nation (all German citizens) and not as the general resident population of Germany. Naturalisation was the only available means of securing the democratic congruence between 'the people' (the electorate of formally equal citizens) and the rest of the resident population (those subject to state authority on a standing basis). Under the Basic Law, the political marginalisation of migrant communities had to be addressed by reforming German immigration law, not electoral law. ${ }^{34}$

This line of reasoning continues to provide the constitutional framework for the political integration of migrant workers 25 years later. The equal citizenship model has been supported by a new generation of constitutional judges, ${ }^{35}$ constitutional scholars, ${ }^{36}$ and successive CDU/CSU gov-

33 BVerfGE 83, 37 [51]; BVerfGE 83, 60 [71].

34 BVerfGE 83, 37 [52].

35 In its Lisbon judgment (BVerfGE 123, 267 [para 292]) the FCC confirmed that 'the democratic legitimation of political rule is [...] not assessed according to the number of those affected'. Patricia Mindus and Marco Goldini, Between democracy and nationality: Citizenship policies in the Lisbon ruling, European Public Law, 18 (2012), pp. 358-364 criticises the Court for its ongoing focus on equal citizenship as opposed to the affected population as basis for democratic legitimacy.

36 Klaus Ferdinand Gärditz, Der Bürgerstatus im Lichte von Migration und europäischer Integration, VVDStRL 72 (2013), p. 51. 
erning coalitions. ${ }^{37}$ In line with the citizenship model, the requirements for naturalisation were twice relaxed during the past 25 years, first on 1 January 2000 to introduce naturalisation through residence, and most recently on 20 December 2014 to allow for naturalisation with dual nationality. From this perspective, the post-apartheid experiment with denizenship and foreigner voting rights at national level would have been (and remains) constitutionally untenable in Germany. Even so, a closer look at the German constitutional argument against the recognition of foreigner voting rights might bring to light what was at stake in that short-lived experiment, and, ironically, provide the impetus for its revival.

The case in Germany for the constitutionality of foreigner voting rights was and remains based on the claim that the principle of democracy requires that 'all affected persons' must be included in the demos. At local government level, this means all permanent residents, regardless of their nationality status. The case thus forced the Court to determine the democratic merits of residence as a principle of political inclusion (and exclusion). As noted above, unlike its South African counterpart, the Court used its two 1990 judgments to explore the meaning of democracy and 'the people' in the context of voting rights and explicitly rejected the 'all affected persons' principle as basis of democratic inclusion.

In his academic support of the Court at the time, Ernst-Wolfgang Böckenförde presented a scathing attack on the 'all affected persons' principle and what he pejoratively called Betroffenheitsdemokratie. ${ }^{38}$ Böckenförde argued that the principle could not be translated into operational constitutional law with sufficient precision to enable 'the people' to play the legitimating function ascribed to it by the Basic Law. For the people to play its

37 The official policy of the CDU/CSU and its coalition partners remains that the right to vote cannot serve as the precondition or catalyst of the successful political and socio-cultural integration of migrants (as argued by the SPD, DIE LINKE and BÜNDNIS 90/DIE GRÜNEN); voting rights is the consequence of a process of integration or naturalisation. The political debates around the issue of foreigner voting rights cannot be further explored here. Suffice to say that the last three German parliaments all considered, but rejected, legislative proposals enfranchising foreign residents. Most recently, on 12 November 2014, DIE LINKE again tabled a Bill extending voting rights to foreigners (after five years of lawful residence, at all three levels of government). See Bundestag, Drucksache 18/3169, 12 November 2014.

38 Ernst-Wolfgang Böckenförde, Demokratie als Verfassungsprinzip, in: Josef Isensee and Paul Kirchhof (eds.), Handbuch des Staatsrechts, Heidelberg, 2004, p. 461. 
foundational constitutional role, it has to form a closed and bounded unity (an assumption which eventually forced Böckenförde to naturalise the nation as a pre-political cultural, linguistic (if not ethnic) unity). ${ }^{39}$ Democratic legality required a formal membership rule. Only nationality was able to meet this demand. Nationality is a permanent and formal status; being affected a subjective and temporal state. As a result, the latter inevitably resulted in a demos which shifted from issue to issue, undermined the formal equality between citizens by grading participation according to the degree of affectedness, and left the demos boundless. Böckenförde warned, reductio ad absurdum, that the principle implied that non-resident foreigners (in category four above) would gain the right to vote in the Bundestag and so determine Germany's immigration policy. ${ }^{40}$

\section{Redefining the 'all affected persons' principle}

Democratic theorists have adopted two main strategies in response to Böckenförde's criticism of the 'all affected persons' principle. The first strategy is to refine and reformulate the principle to limit its scope. ${ }^{41}$ The second strategy, which I wish to highlight here, has been to combine or supplement the 'all affected persons principle' with other principles of democratic self-government to achieve the same result. Robert Dahl already suggested in 1970 that the wide reach of the 'affected interests' principle needed to be 'curbed' by criteria of competence, size (economy of scale), and political equality in order to arrive at a workable definition

39 Böckenförde, note 38, p. 466.

40 Robert Goodin, note 5, p. 64 agrees that the 'all possibly affected persons principle' means that 'we should give virtually everyone a vote on virtually everything everywhere in the world'. Unlike Böckenförde he regards this transnational effect of the principle as one of its strengths, not weaknesses. Goodin pulls the sting of the reductio by conceding that a worldwide franchise for non-resident foreigners is impractical. Other modalities of participation and representation need to be found. Goodin suggests two possibilities: an upwards appeal to a transnational level of government and a lateral claim to compensation for decisions that directly affect outsiders (category four claims).

41 Nancy Fraser, note 3, p. 36 (all persons subjected to a regime of governance); Rainer Baubock, Stakeholder citizenship and transnational political participation: A normative evaluation of external voting, Fordham LR 75 (2007), p. 2421 (all persons with a stake in the future of a polity). These reformulations do not affect the principle of universal residence based voting rights. 
of 'the people' as a self-governing constitutional subject. ${ }^{42}$ This approach to the 'all affected persons principle' was taken up again by Brun-Otto Bryde in the 1990s, in order to arrive at a pluralistic principle of democracy. ${ }^{43}$

Bryde's pluralistic conception of democracy combines competing principles of inclusion in order to secure an optimal degree of democratic selfgovernment. In sharp contrast to the approach of Böckenförde, this approach treats democracy as an aspirational principle and not a legitimacy rule. Bryde nevertheless shares Böckenförde's concern with the boundless nature of the demos associated with the 'all affected persons' principle. Bryde's answer is that not everybody who might possibly be affected needs to be included in the demos, not because it is logically incoherent or absurd to apply the principle so strictly, ${ }^{44}$ but because the criteria of affectedness (the quantity of participants) must be balanced with the criteria of self-government (the quality of the participation). How the optimal balance and degree of democratic self-government can be achieved is a political judgment. Depending on the context, the optimum level of self-government may lie either beyond the level of the state (in a transnational public sphere) or below the level of the state (in a large city).

Sarah Song recently presented her own version of a pluralistic conception of democracy and the 'all affected persons' principle. ${ }^{45}$ Song insists that the demos must remain bounded to the territorial state for much the same reasons Bryde did earlier. She adds that the quality of self-government requires that the 'all affected persons' principle must be balanced with issues of size, stability, and solidarity.

When these added considerations are accounted for, the restated 'all affected persons' principle can operate effectively as a principle of democratic inclusion at the national level. As Bryde reminds us, at lower levels

42 Robert Dahl, After the revolution? Authority in a good society, New Haven, 1970, p. 66.

43 Brun-Otto Bryde, Das Demokratieprinzip des Grundgesetzes als Optimierungsaufgabe, in: Thomas Blanke and Christina Lüttmann (eds.), Demokratie und Grundgesetz, Baden-Baden 2000, p. 59; Brun-Otto Bryde, Ausländerwahlrecht und grundgesetzliche Demokratie, JZ 44 (1989), p. 257.

44 As argued against the principle by Fredrick Whelan, Prologue: Democratic theory and the boundary problem, in: James Pennock and John Chapman (eds.), Liberal democracy, New York, 1983, p. 22.

45 Sarah Song, The boundary problem in democratic theory: why the demos should be bounded by the state, International Theory 4 (2012), p. 39. 
of government the principle far out-performs the principle of citizenship, which cannot explain the democratic gain that is achieved by the constitutional devolution of power in order to ensure optimal democratic governance at local government level. The same applies at higher levels of government above the state, where citizenship is equally incapable of (if not subversive of) achieving optimal levels of democratic governance under conditions of globalisation. In short, when dealing with local issues the principle of citizenship is over-inclusive; when dealing with global issues, such as migration and climate change, the principle of citizenship is under-inclusive. ${ }^{46}$ I return to this point later.

Limiting our attention for the moment to the national level, Bryde and Song both accept that residence provides the best measure across the range of considerations mentioned above (size, stability and solidarity) for the constitutional operationalization of their reformulated 'all affected persons' principle at local and national levels of government. Once the principle of 'all affected persons' is operationalised through permanent residence, it turns out to do the same work that Böckenförde claimed only nationality could do. In fact, residence better captures the full range of persons directly affected over an electoral period by the legislative authority within a state, without thereby sacrificing the stability and solidarity required of a territorially bounded self-governing demos. ${ }^{47}$

The rehabilitation and operationalisation of the 'all affected persons principle' on the basis of residence is today supported by a large and growing number of German constitutional theorists of Betroffenheitsdemo-

46 Nancy Fraser, Scales of Justice: Reimagining Political Space in a Globalizing World, Cambridge, 2008, p. 21 describes this exclusionary effect as the 'injustice of misframing'. She claims, p. 65, that the injustice can only be overcome if the 'all subjected persons principle' is applied directly to issues such as global migration, without mediation of the principle of citizenship. The upshot is that the political injustice inherent in national migration laws and policies can only be overcome, according to Fraser, p. 69, by imagining 'new global democratic institutions'. Böckenförde's reductio is resolved by granting foreign nationals voting rights, not in the national legislature, but in a transnational or global legislature.

47 This claim remains contested but cannot be debated in more detail here. I have relied on the work of Jane Jacobs to argue that (urban) residence indeed generates its own form of political solidarity, or what I call 'street democracy'. See Wessel le Roux, Planning law, crime control and the spatial dynamics of post-apartheid street democracy, SA Public Law 21 (2006), p. 25. 
kratie. ${ }^{48}$ The debate among these constitutional theorists is no longer whether democracy implies universal residence based voting rights, or not, but whether voting rights should be limited to permanent, ${ }^{49}$ and lawful, ${ }^{50}$ residents.

All this can be (and has been) conceded by those who claim that foreigner voting rights remain undemocratic and unconstitutional under the German Basic Law. The point is not whether, in principle or theory, all lawful and permanent foreigners have a democratic right to be represented, but whether this model of denizenship is compatible with the definition of 'the people' in the Basic Law. The outcome of the debate about this issue is not decisive for the future of denizenship under the post-apartheid constitution. It is nevertheless instructive to briefly look into this aspect of the German response to migration as well. As will be seen below, the principle of affected interests (or ordinary residence) plays a surprisingly prominent role in what is usually regarded as judicial celebration of German nationality.

\section{Reinterpreting the Basic Law}

At the end of the foreigner voting rights cases of 1990, the Court qualified its own interpretation of article 28(1) of the Basic Law by stating that the judgment does not exclude the possibility of a constitutional amendment to introduce foreigner voting rights as part of Germany's ongoing political

48 See Thomas Gro $\beta$, Das demokratische Defizit bei der Grundrechtsverwirklichung der ausländischen Bevölkerung, KJ 3 (2011), p. 303 (residence based voting rights are mandated at the national level by basic human rights norms); Christian Walter, Der Bürgerstatus im Lichte von Migration und europäischer Integration, VVDStRL 72 (2013), p. 7 (residence based voting rights are permissible at the national level); Jürgen Bast, Denizenship als rechtliche Form der Inklusion in eine Einwanderungsgesellschaft, 33 (2013) ZAR, p. 353 (voting rights are permissible at national level).

49 Ludvig Beckman, Is residence special? Democracy in the age of migration and human mobility, in: Ludvig Beckman and Eva Erman, (eds.), Territories of citizenship, London, 2012, p.18 (tax law, as opposed to immigration law, should form the basis of residence based voting rights).

50 Ludvig Beckman, Irregular migration and democracy: the case for inclusion, Citizenship Studies 17 (2013), pp. 48 and 55 (irregular immigrants should be given participatory rights because they are equally subject to or affected by the norms of the legal system). 
integration into the European Union. ${ }^{51}$ The anticipated amendment to the Basic Law took place in 1992 when article 28(1) was amended to recognise the right of resident foreigner to vote (provided they were European citizens). Did this amendment render the earlier judgments obsolete (as the Court itself seemed to suggest)? Could the Basic Law be reinterpreted and further amended to extend voting rights to all foreigners at all levels of government according to the principle of democratic inclusion?

After years of uncertainty about the ongoing authority of the 1990 judgments, the Constitutional Court of Bremen ruled on 31 January 2014 that the interpretation of the Federal Constitutional Court remains operative. ${ }^{52}$ As a result, the Court again declared unconstitutional a new attempt to extend voting rights in the city state of Bremen to foreigners from European member states, and at the level of neighbourhood councils within Bremen to all resident foreigners. The judgment nevertheless contains an important dissenting voice in which all the major arguments in favour of the constitutionality of foreigner voting rights are incorporated. Sacksofsky J ruled that the pre-Maastricht Treaty judgments of 1990 were no longer authoritative, that article 28(1) had to be re-interpreted in light of the 1992 amendment, that the starting point for the re-interpretation was the principle of democracy, and that under the Basic Law this principle meant the following: ${ }^{53}$

Those who are subject to the authority of the State should have a free and equal say in how this authority is exercised. It follows from the principle of democracy that everybody who is affected by the exercise of state power should participate in constituting this power. The key element in this right of co-determination is participation on the basis of a universal, free and equal right to vote. [...] The claim to free and equal participation in all public authority is moored to the dignity of all human beings.

The majority and minority judgments differ on the question whether German constitutional law has, over the past 25 years, undergone a shift from a nationalistic understanding of democracy and the people (citizenship) to a post-nationalist conception of the people (denizenship), or from a Volksdemokratie to a Befroffenheitsdemokratie. However this question is

51 BVerfGE 83, 37 [59].

52 Staatsgerichtshof der Freien Hansestadt Bremen, Urteil vom 31. Januar 2014 (St $1 / 13)$.

53 Staatsgerichtshof der Freien Hansestadt Bremen, Urteil vom 31. Januar 2014 (St 1/13), p.24. 
finally resolved, the German foreigner voting rights cases provide the link between residence based voting and democracy that remains unarticulated in the post-apartheid voting rights jurisprudence.

What then about the right of migrant workers abroad or non-resident citizens? If the Basic Law indeed entrenches a nationalist conception of the people, does German law provide further support for the recent recognition of expatriate voting rights in South Africa?

\section{The voting rights of non-resident (expatriate) citizens}

According to article 12(1) of the Federal Election Law, citizens are only eligible to vote in an election if they had their place of residence or habitual abode in Germany for three months immediately before that election. This surprisingly strict durational residence requirement automatically disenfranchises all Germans living abroad, whether temporarily or permanently. German electoral law thus surprisingly imposes a far stricter residence requirement than ever applied under post-apartheid law. How can this strict residence test be reconciled with the strict nationality test which the Basic Law imposes on voters? What is it about being a resident that trumps being a citizen when it comes to inclusion in 'the people'?

Since the re-unification of Germany in 1990, the Bundestag has tried on a number of occasions to limit the exclusionary effect of the strict durational residence requirement by inserting an exception in favour of nonresident citizens into article 12(2) of the Act. At the time of re-unification, article 12(2) provided that German citizens who lived abroad in Europe could still vote in national elections, provided they had lived in Germany for three months before moving abroad. German citizens who lived outside Europe, could do the same, but had to have lived in Germany for three months within the last 10 years (extended to 25 years in 1998). The Act was again amended shortly before the 2009 election when a uniform prior residence requirement of three months was imposed on all Germans living abroad.

On 4 July 2012, the Court declared the exception in article 12(2) unconstitutional. ${ }^{54}$ The judgement left all non-resident citizens disenfranchised

54 BVerfGE 132, 39. This does not mean that the extension of voting rights to nonresident citizens is unconstitutional in itself. Voting rights for non-resident citizens are neither mandated nor prohibited under the Basic Law. 
shortly before the 2013 national election. The 2012 judgment followed a long series of cases dating back to 1956 in which the Court repeatedly held that the durational residence requirement (and its exceptions) did not violate the equal right to vote under the Basic Law. ${ }^{55}$ The Court initially explained the constitutionality of the residence requirement as a practical consequence of the post-war division of Germany, ${ }^{56}$ and later as a historical feature of German constitutional law (dating back to 1869).$^{57}$ In its 2012 judgment, the Court added two additional explanations for the residence requirement. In terms of the first, the residence requirement serves to secure the democratic character of German elections or the 'communicative function' of voting. ${ }^{58}$ The actual and prior residence requirements test the 'capacity' of citizens to participate meaningfully and deliberatively in German politics. ${ }^{59}$ In this sense the residence requirement is similar to the age and mental capacity requirements. In the case of second and third generation emigrants, who can acquire citizenship via the ius sanguinis, the ability to contribute meaningfully to public opinion and political debate (which includes elections) can only be cultivated by actually living in Germany. ${ }^{60}$ The purpose of the residence requirement is to distinguish active deliberative citizens from formal and virtual citizens. ${ }^{61}$ Once the constitutionality of this policy objective is accepted, the reason for the Court's concern with the blanket three months prior residence test becomes clear. The test did not properly differentiate between those expatriate citizens who had acquired the capacity to contribute meaningfully to public opinion and those who had not. For example, an expatriate citizen

55 BVerfGE 5, 2; BVerfGE 36, 139; BVerfGE 58, 202.

56 BVerfGE 5, 2 [6].

57 BVerfGE 36, 139 [142] and BVerfGE 58, 202 [205].

58 BVerfGE 132, 39 [50].

59 BVerfGE 132, 39 [52]. Capacity testing is typical of the republican tradition of constitutionalism, see Jacob Cogan, The look within: Property, capacity, and suffrage in nineteenth-century America, Yale LJ 107 (1997), 473.

60 BVerfGE 132, 39 [54].

61 The Court accepted the view that social media and other communication media do not suffice to cultivate the capacity to participate in expatriate citizens (BVerfGE 132,39 [53]). Once actual residence is foregrounded in this manner, a potential incoherence in the German response to the voting rights of migrants becomes clear: if a second or third generation emigrant can undergo the necessary acculturalisation by temporarily living in Germany for three months as a teenager, why is the same not possible for a first generation immigrant who permanently lives in Germany as an adult? 
who had lived in Germany as a baby would meet the three months prior residence test, but would not thereby have acquired an understanding of German politics. ${ }^{62}$

The second explanation of the residence test is of direct concern to our discussion. The Court explicitly considered, but eventually held that it was unnecessary to decide, ${ }^{63}$ whether the residence requirement may also be used to exclude non-resident citizens who are not 'equally affected by' or equally 'subject to German sovereignty' when compared to citizens who live in Germany. ${ }^{64}$ The 'all affected persons' principle resurfaces again. This time it is embraced by the Court itself as a potentially valid and decisive principle of democratic inclusion. While the Court did not explicitly rule that the 'all affected persons' principle overrides the 'equal citizenship' principle, the Bundestag accepted that it did and explicitly adopted the 'all affected persons' principle as voter eligibility criteria when it reenacted a new residence test before the 2013 national elections. In terms of the current test, unless a non-resident citizen can prove that he or she has direct personal experience of, and is 'affected by' the German political process ('von ihnen betroffen sind'), he or she can only vote in a national election if he or she has lived in Germany (i) for an uninterrupted period of three months, (ii) within the past 25 years, (iii) as a teenager or adult (after his or her $14^{\text {th }}$ birthday). ${ }^{65}$

It is worth noting here that Germany's disqualification of migrant workers abroad was approved by the erstwhile European Commission of $\mathrm{Hu}-$ man Rights in Luksch $v$ Germany. ${ }^{66}$ The Commission held that the exclusion of non-resident citizens from elections did not violate the right to vote

62 The merits of this attempt to link residence with the deliberative character of democracy falls outside the focus of this essay and must be left for another occasion. On the distinction between statistical and deliberative democracy in the postapartheid context, see Democratic Alliance v Masondo [2002] ZACC 28; 2003 (2) SA 413 (CC).

63 Even if it was legitimate to apply the 'all affected persons' test to exclude nonresident citizens, the three months prior residence test provided no indication of who were affected and who not.

64 BVerfGE 132, 39 [52]. Even if this objective was legitimate, the three months prior residence test would remain an arbitrary test for voter eligibility (being equally affected by the legislative authority of the Bundestag).

65 Article 12(2) of the Federal Elections Act (as amended by the $21^{\text {st }}$ Amendment Act on 3 May 2013).

66 Luksch v Germany [1997] ECHR 198, 21 May 1997 (application 35385/97). 
because democracy implied a direct 'correlation between the right to vote and being directly and equally affected by the acts of the political bodies so elected'. The Commission held that a State need not establish, on an individualised basis, whether a person is 'directly affected' by the acts of a particular political body. States are allowed to apply a uniform residence test to establish the correlation between representation and affectedness. The Commission concluded that, as a general rule, a non-resident citizen 'cannot claim to be affected by the acts of political bodies to the same extent as resident citizens'. This line of reasoning was recently confirmed by the European Court of Human Rights in Shindler $v$ UK. ${ }^{67}$ The Court confirmed that the right to vote was not violated by an expatriate voter eligibility test which required prior residence in the UK during the past 15 years. As the Court put it, the prior residence requirement was justified as a means to confine the parliamentary franchise of a State to those citizens 'who would $[\ldots]$ be most directly affected by its laws' ${ }^{68}$

\section{E. Conclusion}

The discussion above reveals how two leading democracies, one from the developed and one from the developing world, are caught between two constitutional models of democracy and political representation. The model of citizenship places nationality (naturalisation) and the principle of 'equal citizenship' central; the model of denizenship places residence and the principle of 'all affected persons' central. The case law discussed above is marked by tensions, contradictions, unexplained shifts and inversions as the Constitutional Courts of South Africa and Germany struggle to navigate their way between these models in search of a new principled basis to regulate the voting rights of migrants.

The discussion above focused on the participation of migrant workers in national elections. I argued that at this level the principle of denizenship

67 Shindler v UK (2013), See also Hilbe v Lichtenstein (1999); Doyle v United Kingdom (2007); Sitaropoulos and Giakoumopoulus v Greece (2012).

68 Shindler note 67, para 118. It should be noted that the European Commission does not share this view. The Commission issued a Recommendation to member states on 29 January 2014 that expatriate citizens should retain the right to vote $(C(2014)$ 391). According to the Commission, the willingness of an expatriate citizen to register as a voter before each election is sufficient to establish the membership link needed to found the right to vote. 
does an equal, if not better, job than the principle of citizenship as voter eligibility criterion. During the course of the argument the question arose whether the principle of citizenship can also secure political justice in local and global processes of governance. The European extension of voting rights to resident foreigners at local government level provides an answer to the first part of the question. What about the second?

Only the 'all affected persons principle' makes a comprehensive democratic response to migration possible, firstly by integrating migrant workers into the national political process of the representative state as residents, secondly, by inviting transnational democratic contestations of the very distinction between visitors, residents and nationals upon which even this denizenship model of representative democracy would still depend. The political injustice towards resident foreigners cannot be remedied by simply extending voting rights to naturalised citizens, or even denizens, without first finding a democratic answer to the question who should count as lawful residents and illegal foreigners in the first place. According to scholars such as Nancy Fraser, ${ }^{69}$ Robert Goodin ${ }^{70}$ and Arash Azibadeh, ${ }^{71}$ this question cannot be answered unilaterally at the national level, without committing the political injustice of excluding foreigners outside the state who are directly affected by the migration laws and policies of the state. As the recent Mediterranean crisis sadly illustrates, the same applies where migration laws and policies are developed at a regional or European level. The principle of equal national of community citizenship is inherently unjust when it comes to the democratic regulation of global migration. This is so because the principle of naturalisation and equal citizenship 'misframes' the problem of migration as the last vestige of national sovereignty to be decided by the nation of citizens alone (as opposed to the transnational or cosmopolitan demos of all possibly affected migrants). ${ }^{72}$

This claim takes us into the contested terrain whether a cosmopolitan demos (humanity as a political category) is conceptually attractive and even possible. ${ }^{73}$ Even if it is not, about which I do not express any opinion here, the point remains that a politically just or democratic solution to mi-

69 Fraser, note 46, p. 25.

70 Goodin, note 5, p. 59.

71 Azibadeh, note 5, p 37.

72 Fraser, note 46, p. 18.

73 Jacques Derrida, On Cosmopolitanism and Forgiveness, London, 2001, p. 51. 
gration, whether at a national or regional level, will have to include foreigners outside the state or the region who are directly affected by border closures and restrictive residence and naturalisation policies (category four claims above). How these foreigners might find political representation within the political decision-making processes of the representative state is a crucial but complex question which I cannot explore in more detail within the space available to me. ${ }^{74}$ The point is simply that the principle of equal citizenship makes it impossible to even raise the participation of foreigners outside the state as a problem of social justice facing the representative state.

It is precisely this (self-imposed) democratic disempowerment which predator states and other governance networks have exploited during the first decades of globalisation. When new social movements try to reassert a right to democratic accountability, they do not do so on the basis of an extension of the principle of national citizenship. They do so in reaction to national citizenship and the representative state, often in the form of a radical anti-institutional participatory political resistance, precisely because the nation state and its representative institutions have become a straightjacket for transformative political energies. ${ }^{75}$ The 'all affected persons' principle, by contrast, provides a link between the national and transnational phases of the democratic struggle for social justice. In a developing country like South Africa, which is particularly vulnerable to the effects of globalisation and neo-colonialisation, ${ }^{76}$ it is crucial to keep this link alive. The dramatic shift from denizenship to citizenship in South Africa's

74 See above footnote 5. For an overview of these options and defence of an administrative law model (as opposed to the constitutional law) model see Eyal Benvenis$t i$, Sovereigns as trustees of humanity: on the accountability of states to foreign stakeholders, American J Int L 107 (2013), p. 295. See also my comments on Goodin in footnote 40 and Fraser in footnote 46 for other modalities of participation short of equal or weighted voting rights for non-resident foreigners in national legislatures (Böckenförde's reductio).

75 Chantal Mouffe, Agonistics: thinking the world politically, London, 2013, p. 65; Judith Butler and Athena Athanasiou, Dispossession: the performative in the political, Cambridge, 2013, p. 140; Manuel Castells, Networks of outrage and hope: social movements in the internet age, Cambridge, 2012, p. 110.

76 John Saul and Patrick Bond, South Africa: The present as history, Johannesburg, 2014, p. 247 writes that 'recolonalization - not by some individual empire but by the Empire of Global Capital itself - is what now confronts ordinary South Africans'. 
voting rights jurisprudence over the past 20 years have, unfortunately, done exactly the opposite. 
